THE THINGS OF LIFE 



\section{THE THINGS OF LIFE}

MATERIALITY IN LATE SOVIET RUSSIA

Alexey GolubeV 
Cornell University Press gratefully acknowledges receipt of a grant from the College of Liberal Arts and Social Sciences, University of Houston, which aided in the publication of this book.

\section{Copyright (C) 2020 by Cornell University}

All rights reserved. Except for brief quotations in a review, this book, or parts thereof, must not be reproduced in any form without permission in writing from the publisher. For information, address Cornell University Press, Sage House, 512 East State Street, Ithaca, New York 14850. Visit our website at cornellpress.cornell.edu.

First published 2020 by Cornell University Press

Printed in the United States of America

Library of Congress Cataloging-in-Publication Data

Names: Golubev, Alexey, author.

Title: The things of life : materiality in late Soviet Russia / Alexey Golubev.

Description: Ithaca, [New York] : Cornell University Press, 2020. Includes bibliographical references and index.

Identifiers: LCCN 2020003685 (print) | LCCN 2020003686 (ebook) | ISBN 9781501752889 (hardcover) | ISBN

9781501752896 (ebook) | ISBN 9781501752902 (pdf)

Subjects: LCSH: Material culture-Soviet Union. Space-Social aspects—Soviet Union. | Soviet UnionSocial life and customs.

Classification: LCC DK266.4. G65 2020 (print) |

LCC DK266.4 (ebook) | DDC 947.085-dc23

LC record available at https://1ccn.loc.gov/ 2020003685

LC ebook record available at https://lccn.loc.gov/2020003686

Cover image: Vitalities of the Ilizarov apparatuses. Photo by Ye. M. Rogov, 1982 . 
To Nastia 
